\title{
Correction to: Assessment of urban sprawl effects on regional climate change using a hybrid model of factor analysis and analytical network process in the Mashhad city, Iran
}

Mohammad Reza Mansouri Daneshvar ${ }^{* *}$, Ghazaleh Rabbani² and Susan Shirvani ${ }^{3}$

\section{Correction to: Environ Syst Res (2019) 8:23} https://doi.org/10.1186/s40068-019-0152-2

Following publication of the original article (Mansouri Daneshvar et al. 2019), the corrected text with the reference citations are given below:

In Introduction, last paragraph, the first sentence should read, "The present paper aims to indicate an integrated procedure of factor analysis and analytical network process named as F'ANP model (established by Zebardast 2013)."

In "Urban sprawl modeling" section, the sentence should read, "The present study generates an urban sprawl modeling for 3 years based on geospatial data and statistical hybrid procedure of factor analysis and analytical network process (F'ANP) (Zebardast 2013)".
Research Institute of Shakhes Pajouh, Esfahān, Iran. ${ }^{3}$ Department of Urban Planning and Design, Mashhad Branch, Islamic Azad University, Mashhad, Iran.

Received: 1 November 2019 Accepted: 1 November 2019

Published online: 12 November 2019

\section{References}

Mansouri Daneshvar MR, Rabbani G, Shirvani S (2019) Assessment of urban sprawl effects on regional climate change using a hybrid model of factor analysis and analytical network process in the Mashhad city, Iran. Environ Syst Res 8:23. https://doi.org/10.1186/s40068-019-0152-2

Zebardast E (2013) Constructing a social vulnerability index to earthquake hazards using a hybrid factor analysis and analytic network process (F'ANP) model. Nat Hazards 65(3): 1331-1359.https://doi.org/10.1007/ s11069-012-0412-1

\section{Publisher's Note}

Springer Nature remains neutral with regard to jurisdictional claims in published maps and institutional affiliations.

\footnotetext{
*Correspondence: mrm_daneshvar2012@yahoo.com

1 Department of Geography and Natural Hazards, Research Institute of Shakhes Pajouh, Esfahān, Iran

Full list of author information is available at the end of the article
}

Springer Open
C The Author(s) 2019. This article is distributed under the terms of the Creative Commons Attribution 4.0 International License (http://creativecommons.org/licenses/by/4.0/), which permits unrestricted use, distribution, and reproduction in any medium, provided you give appropriate credit to the original author(s) and the source, provide a link to the Creative Commons license, and indicate if changes were made. 